\title{
Austrian Corporatism - erosion or resilience?
}

\author{
Susanne Pernicka1, ${ }^{*}$, Günter Hefler ${ }^{2}$ \\ 1 Johannes Kepler University Linz, Institute for Sociology, Linz, Austria \\ 2 3s research laboratory, Vienna, Austria \\ * E-Mail: Susanne.Pernicka@jku.at
}

\begin{abstract}
Notwithstanding ongoing processes of liberalisation and disorganisation in all capitalist economies, Austrian Corporatism has been found to display a remarkable resilience across distinct institutional fields. The focus of this article is on the role of social actors in (re)producing or changing institutional structures and practices of Austrian Corporatism. In the four fields investigated, i.e., economic and social policy making, collective wage bargaining, employment relations at enterprise level and vocational education and training, collective actors have contributed to an institutional conversion of corporatist institutions towards new purposes in an internationalised context rather than to institutional erosion. However, during the government coalition of the Conservative People's Party and the right-wing populist Freedom Party (2000-2006) it became clear that the normative commitment to Social Partnership would reach the limits of its capacity if the power-balance shifted towards a more neoliberal stance. Non-market institutions are therefore seen as providing 'borrowed stability' rather than a robust basis for the resilience of Austro Corporatism. Trade unions in particular are required to shift their orientation towards their membership and find new ways of combining their role as Social Partnership organisations and social movements in order to safeguard non-market institutions.
\end{abstract}

\section{Schlüsselwörter}

Austria, collective wage bargaining, industrial relations, initial vocational education and training, public policy making, social partnership, varieties-of-capitalism

\section{Österreichischer Korporatismus - Erosion oder Resilienz?}

\section{Zusammenfassung}

Ungeachtet der fortdauernden Liberalisierungs- und Desorganisierungsprozesse in allen kapitalistischen Ökonomien weist der österreichische Korporatismus eine erstaunliche Resilienz über verschiedene institutionelle Felder auf. Der Aufsatz fokussiert auf die Rolle von sozialen Akteuren in der (Re-)Produktion oder dem Wandel von institutionellen Strukturen und Praktiken des österreichischen Korporatismus. In den vier untersuchten Feldern, d.h. der Wirtschafts- und Sozialpolitik, kollektiver Lohnverhandlungen, der Arbeitsbeziehungen auf Betriebsebene und der beruflichen Aus- und Weiterbildung, haben kollektive Akteure nicht zu institutioneller Erosion, sondern zu einer institutionellen Konversion von korporatistischen Institutionen in Richtung neuer Ziele in einem internationalen Kontext beigetragen. Während der Regierungskoalition der konservativen Volkspartei und der rechtsstehenden, populistischen Freiheitlichen Partei (2000-2006) wurde allerdings deutlich, dass das normative Bekenntnis zur Sozialpartnerschaft dann an seine Grenzen stößt, wenn sich das Machtgleichgewicht zugunsten einer stärker neoliberalen Position verschiebt. Nicht-marktbestimmte Institutionen stellen daher eher eine ,geliehene Stabilität“ zur Verfügung, als eine robuste Basis für eine Resilienz des Austro-Korporatismus. Gewerkschaften sind im Besonderen gefordert ihre Aufmerksamkeit auf ihre Mitglieder zu richten und neue Wege zu finden, wie sie ihre Rolle als Sozialpartnerschaftsorganisationen und soziale Bewegungen kombinieren können, um die nichtmarktbestimmten Institutionen zu bewahren.

\section{Keywords}

Österreich, kollektive Lohnverhandlungen, berufliche Erstausbildung und Weiterbildung, Politikgestaltung, Sozialpartnerschaft, Varianten des Kapitalismus

The authors have declared that no competing interests exist. 


\section{Introduction}

In international comparison, Austria stands out for its high degree of coordination between organised business and labour (e.g., trade unions) as well as the stability of its industrial relations institutions and collective bargaining practices of wage determination. According to the Varieties-of-Capitalism (VofC) framework (Hall/Soskice 200I; Hall/Gingerich 2004; Thelen 2014) Austria's economic performance and social wellbeing to a large extent rests on non-market institutions. These institutions include

- a firmly established Social Partnership between major interest groups and government in economic and social policy making and administration,

- a collectivist skill formation system with firm-sponsored initial vocational training and an active role of the state in it (Busemeyer/Trampusch 2012),

- a labour market, where occupations are the key institution for organising work and linking the worlds of education and employment (Müller/Gangl 2003),

- multi-employer collective bargaining of wages and working conditions at sector level,

- a system of co-determination at enterprise and plant level and

- high levels of employment protection for the majority in the workforce.

European challenges (e.g., the shift of competencies to the supranational level after the accession of Austria to the European Union in 1995) and global economic pressures during the latest crisis since 2008 (Gallie 2013) have not disentangled these national institutions but rather seemed to have reinforced Austrian Corporatism. Some observers suggested to subsuming strategies to overcome the current crisis under the notion of crisis corporatism because they were built upon patterns of plant-level-cooperation that Austrian firms have pursued for many decades. Crisis corporatism is thus understood as a revitalisation of traditional NeoCorporatism ${ }^{\mathrm{I}}$ in Austria that had evolved in the post-WWII

I Both notions coordinated market economy and neo-corporatism emphasise the role of non-market institutions and collective agency in the organisation of capitalist societies. While the more recently developed VofC-framework distinguishes between Coordinated Market Economies (CMEs) and Liberal Market Economies (LMEs) as institutional configurations with a certain 'Eigenlogik' (logic of action) and a focus on the strategic orientations of employer organisations, neo-corporatist literature was developed during the I970s as a critical stance against both, orthodox Marxism and pluralist industrialism, and underlined the importance of labour strength. Against orthodox Marxism, neocorporatist literature emphasises the diversity of social institutions into which modern capitalism has been nationally organised. These institutions have substantially modified some of the alleged 'laws of motion', most importantly, the deterministic assumption that capitalism would finally be overcome by a revolution of the proletariat. Against pluralist industrialism, corporatist literature insisted on the continuing significance of corporatist agency in particular national production regimes (Streeck 2OIO, I2). In comparison to neo-corporatist literature, the VofC-Framework with its emphasis on economic efficiency and the behaviour of firms within institutional regimes, no longer takes era. Since 1945 hierarchically organised interest groups (e.g., the Chamber of Commerce and the Chamber of Labour) have been granted with exclusive rights and perform quasi-public functions (Schmitter 1974; Streeck/Schmitter 1985; Traxler 1992). Rather than conflict, cooperative relations between labour and capital at enterprise and plant level, at sector level and at macro-political level turned out to provide a successful route of (high road) adjustment to external and internal challenges. ${ }^{2}$ During the most recent crisis negotiations between organised labour and business as well as representatives of the state took place at all of these different levels. These negotiations in turn prevented job losses and retained a highly skilled labour force, particularly in manufacturing. As a means of reducing labour costs and avoiding job losses firms made use of working-time reductions and increased working-time-flexibility (Flecker/Schönauer 20I3). By international comparison, these measures have kept the level of unemployment in Austria comparatively low.

From a country-comparative perspective, Austria provides an interesting and under-researched case $^{3}$ that seems to confirm a core premise of the VofC Framework (Hall/Soskice 200I; Hall/Gingerich 2004). Early accounts of VofC presume that institutional complementarities within and across spheres in a political economy occur because they provide efficiency to the system as a whole. According to Hall and Soskice (200I: 27) two institutions can be said to be complementary if the presence (or efficiency) of one

account of macro-social forces within capitalist political economies.

2 Austrian neo-corporatism is well established both structurally (interest group set-up) and procedurally (e.g. involvement of the Social Partners in public policy making, sector wage bargaining and in jurisdiction, where lay judges participate in labour court proceedings and appoint assessors for the cartel court). However, while corporatist institutions seem to remain relatively stable, since the I980s social partnership organisations have lost significant parts of their power of influence, such as in economic and social policy making (Tálos 2008). In regard to wage bargaining, the shift from Keynesianism to orthodox (i.e. liberal) approaches in macro-economic policy also changed the functions of coordination (see the sections below). Classic social partner institutions are the Chamber of Commerce (Wirtschaftskammer, WKO), the Chamber of Labour (Bundesarbeitskammer, BAK), the Conference of Presidents of the Chambers of Agriculture (Präsidentenkonferenz der Landwirtschaftskammern, PRÄKO) and the Austrian Trade Union Federation (Österreichischer Gewerkschaftsbund, ÖGB). It is noteworthy that the Federation of Industries (Industriellenvereinigung, IV) had been seen as a traditional member of Austrian Social Partnership until the I990s. However, meanwhile the IV has been regarded as a political lobbying organisation (Karlhofer 2007).

3 Besides existing publications that focus on specific fields (e.g. public policy making, collective wage bargaining, vocational education and training, etc.) of Austro-Corporatism, the seminal work of Peter Katzenstein (1984) in which he develops a systematic comparison of the small open economies Austria and Switzerland and their corporatist traditions provides a notable piece of research. 
increases the returns from (or efficiency of) the other. Complementarities between institutions located in different fields of a political economy are particularly important. To take one example from the evolving cross-country comparative literature on skill formation systems 4 : Long-term employment, for instance, is more feasible where firms have contributed financial resources to the formation of general and firm-specific skills of their workforce and strongly rely on medium levels of skills with low proportions of unskilled work. Contrary to countries with a low skill equilibrium such as the UK, firms in Austria follow a high skill equilibrium and display a very small proportion of low skilled workers short term temporary agency workers being a notable exception. The wide use of qualified workers with firmspecific knowledge provides a disincentive to hire and fire practices. Conversely, fluid labour markets may be more effective where universal skills of employees and high levels of skill polarisation with a low level of medium skills exist and the state and households carry the main costs of generating skills (, Esteves-Abe et al. 200I). Due to their functional complementarities, and following the premises of the VofC approach, institutional configurations are assumed to remain stable even in times of societal change. Hence, different institutional arrangements in Liberal Market Economies (LMEs) and in Coordinated Market Economies (CMEs) are supposed to remain different. In the Austrian political economy

4 As an object of analysis, skill formation systems refer to the interpenetration of work organisation, the use of and distribution of skills across workplaces within and across organisations and the initial (vocational) education system. While differing in their theoretical points of departure, research on skill formation systems seems on its way to become a field of research in its own right (different from studies on initial or continuation vocational education). Key contributions to the field typically derive from contrasting skill formation systems of two (or two groups) of countries, allowing for concepts reflecting key differences in the ways skills are produced, distributed and used. In their seminal contributions, Maurice et al. 1987 contrasted France and Germany, sketching the opposition between 'organisational' and 'occupational' spaces. Koike and Inoki (1990) introduced the key differences between systems as in Japan, where all workers are typically required to deal with the routine and the exceptional requirements of the work processes, versus systems as the US or the UK, where different layers of workers deal with routine and exceptional issues. In studies comparing the UK and Germany (Maurice et al. 1980; Finegold/Soskice 1988; Streeck 199I), the ideal type dichotomy between a 'low skills' and 'high skills' equilibrium was introduced. While the former, as in the UK, is characterised by a large share of low skilled workers and low shares of workers holding medium levels of vocational skills, the latter as in Germany combines a small proportion of unskilled helpers and large proportions of workers holding vocational qualifications on medium level. For an early synthesis see Ashton and Green, 1996). Review of the literature are given in Thelen $(2004 ; 2008)$ and Crouch $(2006)$. Edited volumes on the field include Mayer/Solga (2008) and Busemeyer/Trampusch (2012). A comprehensive framework for analysis is presented by Green (2OI3). The literature on skill formation systems partly intersects with the VofC literature, with Esteves-Abe, Iverson and Soskice as an important link between the two strains of work. We describe the Austrian skill formation system in section IV against the backdrop of the sketched literature. business, labour and state actors have indeed contributed to the reinforcement of non-market institutions of cooperation across different fields during the crisis. Skilled employees, accounting for the majority of the workforce, with a combination of vocational qualifications and firm-specific skills (an outcome of collectivist firm-sponsored VET) could be retained through collective agreements between organised labour and capital (an outcome of the traditional social partnership system) which in turn reduced unemployment (an outcome of traditional structures and practices that facilitate internal flexibility rather than external flexibility) and reinforced the 'high-skills equilibrium' instead of LME typical skill polarisation with its large low skilled segments strongly exposed to unemployment in times of economic slowdown.

However, evidence of successful crisis management by the means of corporatist relations does not suffice to confirm VofC premises. Similar responses to the economic crisis have been observed in Germany, where Streeck (2010) convincingly demonstrated that nonmarket institutions of co-operation have independently from each other eroded in several spheres over the last few decades. While the German political economy still differs from liberal market economies in terms of its formal institutional configuration, processes of dis-organisation and erosion of non-market institutions have challenged a core thesis of the original VofC-Framework. Business, state and even labour actors in Germany have contributed to undermine CME institutions, in particular at the fringes of the production systems and in the growing private service sector (Streeck 20IO; Hassel 20I4).

Given the multiple pressures associated with globalisation, de-industrialisation and ideological neoliberalism collective actors in CMEs such as Austria are challenged and might contribute to incremental change towards liberalisation (Streeck/Thelen 2005; Streeck 20I0; Thelen 20I4). However, while subject to similar economic and political pressures actors' responses in different countries vary according to their institutional embeddedness within respective political economies (Thelen 20I4). Institutions are perceived as outcomes of historical struggles over the distribution of symbolic and material resources. Accordingly, we expect that the extent to which collective actors resist, give way to or even exert liberalisation pressures in CMEs depend on their willingness and ability to internalise contradictions and conflicts that arise from the dynamics of the capitalist system itself (Streeck 20IO; Baccaro/Howell 20II; Thelen 2014) rather than on their functional contribution to systemic efficiency. Moreover, we assume that actors are also able to create new non-market institutions even in times of increasing pressures of liberalisation. An example refers to vocational education 
and training in Austria where supra-company training programmes (überbetriebliche Lehrausbildung) for young workers without regular apprenticeship positions have been established to compensate for lacking business activities.

In this paper, we are therefore less concerned with the outcomes (efficiency of political economies) of institutional configurations in Austria, but concentrate on the interrelationship between structures and behaviour of collective actors. Institutions are supposed to condition collective actor's behaviour and the same time they are (re)enacted by business, labour and state actors. In our investigation of four different fields of the Austrian political economy we therefore address the following question:

'What role have Social Partners, political parties and other collective actors in Austria played in reproducing or changing institutional structures and practices of neo-corporatism in selected fields?'

In terms of the time frame we concentrate on developments since the early I980s when Austria, like many other political economies, has faced an ideological turn from Keynesianism towards a supply-oriented regime. In Austria we argue that this regime transformation was a case of institutional conversion, i.e. existing institutions are redirected to new purposes, driving changes in the role they perform and/or the functions they serve (Thelen 2004, 225-226), rather than institutional erosion. We present empirical data derived from secondary literature and official statistics that support or challenge our contention that Austrian Corporatism has remained widely intact by taking on new roles and functions.

\section{Cultures of Austrian Corporatism}

According to Hall and Soskice (2OOI, 4), the most important institutional structures of (liberal or coordinated) market economies depend on the presence of regulatory regimes that are the preserve of the nation state. The Austrian system of neo-corporatism rests on regulatory norms, such as the Labour Constitution Act (Arbeitsverfassungsgesetz) which provides the basis of co-determination at enterprise and plant-level. Most importantly, trade unions benefit from the compulsory membership of employers in the Chamber of Commerce (Wirtschaftskammer, WKO) established under Austrian law la $^{5}$ In wage

5 Besides compulsory membership of business organisations in the WKO which makes collective agreements legally binding to all employers, trade unions benefit from the so called erga omnes principle which refers to the extension of the applicability of collective agreements to all employees even if they are not members of a trade union (Traxler and Behrens 2002). More recently in a number bargaining, the WKO and the Trade Union Federation (ÖGB) and their respective sub-sections and member unions conclude collective agreements for almost all industries in the private sector. Since collective agreements are legally binding for all of WKO's mandatory members, collective bargaining coverage in Austria is exceptionally high. Almost Ioo percent of the labour force is covered by a collective agreement (Bauer 20IO). However, neo-corporatism in general and the important role of major interest groups in public policy making in particular to a large extent hinge also on non-regulative, cultural norms. In comparison to neo-corporatism as the more generic term for a culture of non-conflictual, compromise oriented behaviour of labour, business and state actors, the notion of consociational democracy (Konkordanzdemokratie or Verhandlungsdemokratie) (Lijphart I999; Müller/Jenny 2004, ) is more specifically applied to the relationship between political parties and government. In consociational democracies conflicts are resolved by negotiations and a search for compromises rather than by party competition and majority rules of decision making (Tálos/Stromberger 2004). While in other areas such as environmental or economic policies the patterns of consociational democracy were never firmly established or have been found to be partly substituted by more pluralist pressure politics (lobbying) in Austria (Tálos/ Kittel 2OOI), in the social and labour law field extensive consultations of and tripartite negotiations between the Social Partner organisations and government are still intense (Falkner/Leiber 2004; Krings 20I3).

However, the political situation in Austria significantly changed between the years 2000-2006, when a centre-right government of the Austrian People's Party (ÖVP) and the right-wing Freedom party (FPÖ, which later was divided into two parties, FPÖ and BZÖ, under the leadership of Jörg Haider) came to power. In comparison to all former Austrian governments since 1945 that were strongly committed to Social Partnership and a political culture of compromise orientation (Tálos/Stromberger 2004), the ÖVP/FPÖ-BZÖ government was hostile towards concertation and FPÖ even restated their longstanding demand to abolish compulsory membership in the Chambers (Tálos/Kittel 200I). Although the law was not changed in this respect, trade unions in particular lost their power of influence in public policy making during 2000-2006. While the situation changed again in favour of trade unions after 2006, when the labour friendly Social Democratic Party (SPÖ) again formed a

of branches, such as private health and social services (BAGS) and further education (BABE), collective agreements have been concluded although employers are not compulsory members of the WKO. Rather, employers established their own voluntary associations (GPA-DJP 2OI5). This development seems to confirm a core premise of sociological neo-institutionalism (DiMaggio and Powell 1984): organisations adopt and follow existing practices and norms of behaviour which predominate in broader institutionalised fields. 
grand coalition with ÖVP, it has become clear that the Austrian Social Partnership is largely built on 'borrowed institutional stability' (Flecker/Hermann 2005).

In the ensuing parts of this paperwe provide an overview of four institutional fields of the Austrian political economy, in which Social Partnership have been traditionally strongly entrenched. These fields include (I) cooperative relations between government and peak-level interest groups in economic and social policy making, (II) multi-employer collective bargaining over wages and working conditions at sector level, (III) managementlabour relations at enterprise and plant-level and (IV) initial vocational education and training. In analytical terms we pursue two aims:

(1) We intend to contribute to a better understanding of processes that might foster or weaken the stability of Social Partnership within the tradition of Austrian Corporatism.

(2) We investigate what role collective actors play in changing or maintaining patterns of Social Partnership.

\section{Four institutional fields of Austrian Corporatism}

(I) Cooperative relations between government and peak-level interest groups in economic and social policy making

Within the VofC-Framework institutions are perceived as historically evolved rules and cultures that impinge on the strategic behaviour and practices of firms, governments, trade unions and employers' associations. Responses to pressures of increasing international economic competition and European integration are presumed to be shaped by existing national institutions. We follow this line of reasoning, however, draw more emphasis on the capacities and willingness of collective actors (so called institutional entrepreneurs, DiMaggio I988) to change and even disrupt institutions and hence economic and policy outcomes. In addition, we perceive power relations between actors as equally important as any functional complementarities of institutions in different fields. However, changes in the balance of power might not lead to institutional change as long as normative orientations remain widely intact and perceived costs exceed expected gains of institutional changes.

One cannot understand more recent developments of Austrian Social Partnership in public policy making unless one takes into account the economic and political transformations since the early I980s. These comprise I) profound economic changes that include an unprecedented rise in unemployment rates (with an early negative peak in 1984), a decline in economic growth rates and increasing international competitive pressures; 2)
Austria's accession to the European Union (EU) in 1995 and its participation in the Eurozone since 1999 that shifted competencies in legislative policy making from the national to the supranational level. Since then, almost all economic policy issues and to a smaller extent social policy and labour law issues have been dealt with and decided at the European level and 3) a rise in neoliberal political orientation in public policy making since the I980s that was not confined to liberal market economies (referred to as Thatcherism and Reaganomics) but also spread in coordinated market economies. These developments in turn undermined the so called basic consensus (Grundkonsens) about overall economic and social political targets and about the predominant role of the state in stimulating the economy from the demand side that characterised the attitudes and identity of Austrian Social Partnership and governments in the I960s and I970s (Tálos 2006, 3). This basic consensus included the growth of the economy and employment, price stability and an equal balance of trade in order to secure and increase the standard of living of the Austrian population. Economic development and social policy making were closely interrelated in this period and economic growth and full employment provided the basis for the expansion of social policy in Austria in the 1960 and I970s. Based on this basic consensus Social-Democratic (SPÖ) governments under Bruno Kreisky (1970-I983) paved the way to economic policies that included overall demand-side management, high levels of government expenditure and full employment - an economic policy mix that is also referred to as Austro-Keynesianism.

The above mentioned challenges, intensifying international market competition, historically high levels of unemployment and ideological changes in particular led to a new political course in macro-economic policy making since the 1980s. Instead of an orientation towards the demand side of the economy, the supply side has come to the centre of political measures, such as budget austerity measures, labour market flexibility accompanied by social security (so called flexicurity) and policies directed towards securing business settlement. This development paved the way to a transformation from demand-side Keynesian to supply-side corporatism (Traxler 2004). In line with this supply-side orientation, former state-owned industries (Verstaatlichte Industrien, e.g. VOEST-Alpine in Linz) were broken apart from the early I990s onwards and several of the resulting firms started to operate largely as private businesses. A great number of these firms were wholly or partially privatised.

All these changes put government, irrespective of party-political composition, and employers' associations closer together, while organised labour (trade unions and the Chamber of Labour) has come under growing pressure. Against this background, the forma- 
tion of the right-wing conservative coalition government between ÖVP and FPÖ in 2000 came as a shock to organised labour as well as to international political observers. ${ }^{6}$ Although the labour friendly Social Democratic Party (SPÖ) won parliamentary elections in 1999, the far-right Freedom Party became the second strongest party by a very small edge before the ÖVP. Since no coalition partner for the SPÖ could be found, the ÖVP under Chancellor Wolfgang Schüssel formed a government coalition with FPÖ. This occurred although Schüssel promised to stay in opposition if his ÖVP would occupy the third position in the election.

Public policy making between the years from 20002006 meant a - temporary - farewell to traditional Social Partnership, i.e. tripartite concertation in social and economic policy issues. In the ÖVP-FPÖ government programme of 2000, in statements of government representatives and the budget-speech of the minister of finance, it became clear that the coalition government pursued a neoliberal course in economic and social policy issues and a gradual disengagement of the state in order to prevent a further increase in public debts (Tálos 2006). Reforming the social security system and in particular the pension system was at the centre of a political programme in which mutual solidarity should be replaced by individual provision for education, health and old age. In 2003, when pension reform was expected to be decided by the majority votes of ÖVP/FPÖ and without involvement of traditional forms of social partnership, ÖGB called out for strike action which had led to the greatest strikes in Austria since the I950s (Mairhuber 2003, 9). However, the pension reform proposed by conservative ÖVP-FPÖ government passed parliament with only small amendments compared to earlier drafts. The new pension system can be expected to induce a further increase in social inequality in Austria. The legal retirement age is 65 for men and 60 for women; old-age pensions are now calculated on the basis of 40 years of insurance (instead of those 15 years with the highest income), which reduces pension payment considerable for persons with longer career interruptions due to unemployment or parental leave.

In response to opposition to government policy proposals from organised labour and SPÖ political reforms were rushed through. Speed kills! was the popular saying within the $\mathrm{OVP}^{7}$ to characterise a situation, in which the

6 The formation of the ÖVP-FPÖ coalition government provoked a huge outcry in Austria as well as abroad, leading even to sanctions by the European Union and Israel pulling out its ambassador in protest against the participation of the far-right FPÖ in government. For the first time in 30 years, SPÖ government was part of parliamentary opposition.

7 It is noteworthy that the General Secretary of the Federation of Industries (IV) has played an important role as 'spiritus rector' in a collaborative attempt of the conservative government and the IV to decouple business interests from public welfare considerations and to enforce a more liberal societal order (Karlhofer 20I2, 544).
ÖGB and the Chamber of Labour were circumvented in favour of a decision making process based on majority rule (Karlhofer 2007, 398f.). At the same time corporatist policy structures were reinforced through the implementation of EU Directives such as the Directive on parental leave, an area where traditionally cooperation between management, labour and the state has been particularly intense (Falkner/Leiber 2004).

When in 2007 a grand coalition of SPÖ and ÖVP came to power again, Social Partnership saw a revival of its role in social policy-making. However, the newly formed coalition government lasted for only I.5 years due to a number of conflicts between the two parties. In July 2008 the ÖVP called for new parliamentary election which in turn led to large decline in votes for both parties. In 2008 the Grand Coalition was renewed and there have been clear signs of a return of consensus democracy in public policy-making (Obinger 2009). While the SPÖ/ÖVP government continued to pursue the path of flexicurity in relation to active labour market policies (Atzmüller 2009) and an economic policy which strengthens the supply side (business), labour representatives have again become social partners to business and government rather than enemies. Concerning the relations between social partners it is noteworthy that in 2006 the corporatist associations concluded the "Bad Ischler Declaration", named after the location where regular meetings take place, which has provided the basis for a renewal of their close interrelationship and consensus seeking attitude (Pernicka/Stern 20II, 336). However, this initiative cannot compensate for the close intertwining of political parties, interest associations and parliament that prevailed between the I970s and I990s and that have been continually dismantled (Karlhofer 2007, 39I). Moreover, at least three indicators point to massive problems of public acceptance and legitimacy of the traditional structures of interest representation on the side of labour: I) Employees lost confidence in the activities of the Chamber of Labour, which all dependent employees are legally obliged to join (civil servants and agricultural workers are exempted). This development is manifested by a steady decrease in voter participation in Chamber of Labour elections from 63\% in 1984 to about $40 \%$ in 2014 (Tálos 2008, 77 f. and Arbeiterkammer 2015). 2) Trade union membership levels have declined considerably over the last decades. Their traditional strongholds in manufacturing are shrinking, while conditions in the services sector (e.g., lower levels of productivity, smaller business entities, a larger proportion of non-standard employment and a lack of works councils) do not provide trade unions with the same organising potential as large industrial corporations. Between 1970 and 201 trade union density as a measure of union membership in relation to total employment fell from 62.8 percent to 27.8 percent (Visser 
2013). And 3) an accelerated speed in trade union membership loss has been triggered by what Tálos $(2008,78)$ called the greatest crisis of the ÖGB since its inception in 1945. Since the mid-I990s BAWAG, the country's fourth largest bank fully owned by ÖGB, had lost more than EUR I billion, mainly on speculation deals in the Caribbean. When this disaster became public in April 2006, the government, major banks and insurance companies together with ÖGB developed a plan to bail out the bank. Under the terms of the plan which needed endorsement by legislation ÖGB was obliged to sell BAWAG. Although the law exempted ÖGB from liquidating related debts to an extent that would make it insolvent, it nevertheless came close to financial collapse (Traxler/Pernicka 2007, 2I2).

However, trade unions have only slowly begun to redirect their attention from the logic of influence (employers and the state) to their constituencies (logic of membership) (Schmitter/Streeck 1999; Traxler/Pernicka 2007; Tálos 2008). In comparison to trade unions in Germany where union leaders have become more dependent on their membership strength, Austrian trade unions to a lesser extent feel a need to engage in organising and retaining (new) members. Though, political developments between the years 2000 and 2006 and more recent conflicts between employers' and employees' associations in collective wage bargaining (see below) have induced trade unions to take a more conflictual stance. In addition, unions have expanded the supply of services to their members, included new member groups (dependent self-employed) and enhanced member participation within their organisations (Pernicka 2005; 2006).

\section{(II) Collective bargaining over wages and working con- ditions at sector level}

Austria exhibits widely intact forms of wage setting coordination, highly centralised structures of industrial relations and a collective bargaining coverage of 96 percent in the private sector (Bauer 20IO). Collective agreements are negotiated, almost without exception, at multi-employer sector level. On the side of organised labour in wage bargaining, the Austrian Trade Union Federation, ÖGB obtains an associational monopoly, encompassing all of the countries' unions and union membership (Traxler/Pernicka 2007). On the side of organised business, the peak organisation of the Austrian Chamber of Commerce, WKO stands out in terms of its associational comprehensiveness. Most collective agreements are concluded by its industry subunits. All businesses covered by the domain of WKO are legally required to be members, so coverage is Ioo percent for companies and employees in all areas where the chamber subunits bargain on behalf of the employers. Although rivals do not exist, ÖGB and WKO have formally reinforced their bargaining position by mutual recognition as the privileged partner for collective bargaining, also and even more so during the time when a right-wing conservative coalition government challenged Social Partnership institutions (see above).

The relatively stable patterns of coordination in wage bargaining contrast with scholarly assumptions about 'disorganised capitalism' since the I980s (cf. Lash/Urry 1987; Streeck 2010). The internationalisation of markets and the ideological turn from Keynesian towards orthodox liberal policy approaches have not only restricted the room for maneuver of national actors. These developments are assumed to be detrimental to (Austrian) corporatism and, so the argument goes, will sooner or later induce a path towards uncoordinated wage determination. However, rather than exhibiting a continuous decay, corporatism has taken on new forms and functions in the Austrian political economy since the 1980 s (see table I).

The classic instrument through which the peak organisations exerted influence is the Parity Commission for Pay and Prices (founded in 1957) which until the late I990s operated on an informal basis and is composed of delegates from the ÖGB, WKO, the Federal Chamber of Labour (AK) and the Conference of Presidents of the Chambers of Agriculture (PRÄKO). Parity stands for equal representation and means, giving organised labour the same number of seats as business and agriculture together. The Parity Commission consists of four subcommittees: the Advisory Council for Economic and Social Affairs, the Subcommittee on International Issues, the Subcommittee on Wages and the Subcommittee on Competition and Prices. After Austria's accession to the European Union in 1995 and due to economic internationalisation, the parity commission has lost most of its significance. The Parity Commission formerly dealt mainly with price controls and combatting inflation. Until the late I990s it provided an institutionalised forum for dialogue between social partners and government. Collective wage bargaining was never a domain of the Parity Commission. However, there is still a formal obligation of the sector employers' organisations and trade unions to apply to the Parity Commission's Subcommittee on Wages for approval before they can commence their pay negotiations.

As has been already mentioned, the peak employers' (Chamber of Commerce, WKO) and employees' organisations (Austrian Trade Union Federation, ÖGB) are legally entitled to conclude collective agreements, however, usually they delegate these competencies to their sector level sub-units, i.e. the seven member trade unions of the ÖGB and the federal and regional subunits of the WKO. Thus, national general agreements (Generalkollektivverträge) between the peak organisations 
Table 1. The metamorphosis of corporatism in Austria

\begin{tabular}{lll}
\hline & Austro-Keynesianism & Supply oriented regime \\
\hline Time period & from the 1970s until the 1980s & from the 1980s onwards \\
\hline $\begin{array}{l}\text { Collective wage } \\
\text { coordination }\end{array}$ & classical patterns of corporatism* & lean patterns of corporatism \\
\hline $\begin{array}{l}\text { Functions of wage } \\
\text { bargaining }\end{array}$ & $\begin{array}{l}\text { Key role in containing active fiscal policy (state } \\
\text { expenditure, demand side management) to prevent } \\
\text { inflation. }\end{array}$ & $\begin{array}{l}\text { Preferred counter-inflationary measure (i.e., tighten } \\
\text { monetary supply) renders classical corporatist }\end{array}$ \\
& $\begin{array}{l}\text { To keep average wage increases at the level of } \\
\text { productivity and inflation ensures sound macro- } \\
\text { economic development and a high level of } \\
\text { flexibility in adapting to external pressures. (e.g. oil } \\
\text { shocks in the 1970s) }\end{array}$ & $\begin{array}{l}\text { New role is to keep wages below productivity } \\
\text { levels and inflation to contribute to sector and } \\
\text { international competitiveness and flexibility in } \\
\text { adapting to external pressures (e.g. most recent } \\
\text { crisis since 2008). }\end{array}$ \\
\hline $\begin{array}{l}\text { Forms of wage } \\
\text { bargaining }\end{array}$ & $\begin{array}{l}\text { Sector level bargaining coordination and intra- } \\
\text { associational coordination across industries }\end{array}$ & $\begin{array}{l}\text { Pattern bargaining coordination with the metal } \\
\text { sector takes role as 'pattern setter' }\end{array}$ \\
\hline
\end{tabular}

* In the early 1950 s there were some central pay agreements, since then bargaining on pay and other terms and conditions of employment has been taken place at the sector level. (Source Traxler 2004)

ÖGB and WKO are very rare and almost never include wage issues. Collective agreements are almost always concluded at the sector level, very rarely at company level. In total, there exist approximately 650 collective agreements, including company level agreements (Bauer 20IO). It is important to note that the public sector is excluded from the right to collective bargaining. Instead the Public Sector Union (Gewerkschaft Öffentlicher Dienst, $G O ̈ D)$ negotiates with the government over pay and working conditions for civil servants and public sector employees.

In the private sector, the metal sector plays the role of a wage leader (pattern bargaining) and usually starts the so-called autumn bargaining round (Herbstlohnrunde). Under the supply-side oriented regime of collective bargaining employers' and employees' associations have developed an interest in increasing and maintaining the competitiveness of exposed sectors by setting moderate wage increases. Collective agreements concluded in metal sector set an informal but effective norm concerning wage increases. The parties to collective bargaining in other sectors follow this norm by concluding wage increases that usually fall below the metal sector agreement.

The development of the wage ratio (i.e., proportion of wages in national income) over the last several decades illustrates the functional distribution effects of pattern bargaining. Real wage increases have remained below national productivity and inflation rates and se- cured advantages vis-à-vis international competitors. In I995 the adjusted wage share (excluding taxes and social security contribution) was $68.1 \%$ and decreased to $58.4 \%$ in 20II (BMASK 20I3: 220) while the profits' share has increased, respectively. This phenomenon - real wage decreases - can also be interpreted as a fare-well to the former solidarity-oriented wage policy which was based on the so-called Benya formula, coined by Anton Benya a former president of the ÖGB, who served from I9631987. This formula includes the recommendation that collective bargaining parties should orient their wage settlements towards the long-term development of inflation and overall productivity in order to ensure that both, workers and employers benefit from increases in productivity. The underlying logic is that the purchasing power of workers should remain relatively stable which in turn stimulates domestic demand for goods and services and hence, the economy. However, as has already been mentioned, the single currency area, preferred counter-inflationary measures of tightening monetary supply, and the internationalisation of the economy render classical corporatist wage bargaining superfluous. International competitive pressures have also been the main line of argument of employers in their continuous efforts to decentralise collective bargaining negotiations. In the autumn bargaining round 2012 the metal sector's largest employer organisation and subunit of the WKO, the Association of Austrian Machinery and Metalware Industries (FMMI), opted out 
from the communal bargaining process. For forty years, six sub-sections of the WKO voluntarily formed a collective bargaining community, while in 2012 the specific subsectoral employer organisations all conducted separate negotiations with the respective unions. However, at least until now (2014) they all resemble each other and the wage increases agreed upon are in the same range in all subsectors (Eurofound 20I4).

In the context of Austria's membership in the Eurozone - the single currency area - wage moderation appears to be problematic. The latest crisis within the Eurozone can partly be explained by macro-economic imbalances caused - among other factors - by uneven nominal wage developments (Hancké 2013, Höpner/ Lutter 2014). These in turn are also a result of wage moderation in those countries exhibiting current account surpluses due to a strong competitive position within the European economy, most notably Germany. Against this background the European Trade Union Federation (ETUC) repeated its recommendation of the year 2000 to apply a coordination rule similar to the Benya formula to all EU member countries (ETUC 2000). This implies that countries like Austria should keep their wage agreements close to productivity and inflation levels rather than concluding wage agreements that fall short of this standard.

However, wage bargaining coordination at sector and macro-economic level requires non-market institutions that cannot be easily built up within a short time (Pernicka/Glassner 20I4). Moreover, current political attempts to tackle the crisis in indebted countries like Greece, Portugal, Spain and Italy (Troika measures) rather support a decentralisation and destruction of industrial relations institutions rather than a strengthening of their capacities to coordinate wage developments (Her-
mann/Hinrichs 2012). Comparative low levels of unemployment in Austria (see figure I) are thus a result of both, institutional stability of its supply-side oriented Corporatism and its strong competitive position within the Eurozone countries. Since countries cannot remedy their current account deficits by the means of currency devaluation within the Eurozone, wage moderation in countries like Austria or Germany contribute to an even greater economic imbalance.

\section{(III) Management and labour relations at enterprise} level

In Austria, interest representation of labour is formally separated between works councils and trade unions. This so-called dual system of interest representation provides labour with two legally enforceable channels of influence: I) trade unions negotiate and conclude collective agreements with organised business at sector level, as outlined in section II of this paper, and 2) works councils are entitled to represent labour at enterprise and plant level. While conflicts over the distribution of income as well as the right to strike fall under the domain of trade unions, works councils act as intermediaries between the labour force and management and lack the right to call for a strike. In legal terms, a works council can be set up within establishments consistently employing five or more workers. The Labour Constitution Act (Arbeitsverfassungsgesetz) equips works councils in Austria with consultation and co-determination rights that go far beyond information and consultation rights provided to European Works Councils in multinational companies. Co-determination in Austria is a structure of decisionmaking that enables works councils to influence management decisions in different ways. For instance, works

Figure 1. Unemployment rates in selected countries of the Eurozone (15-74 year-olds)

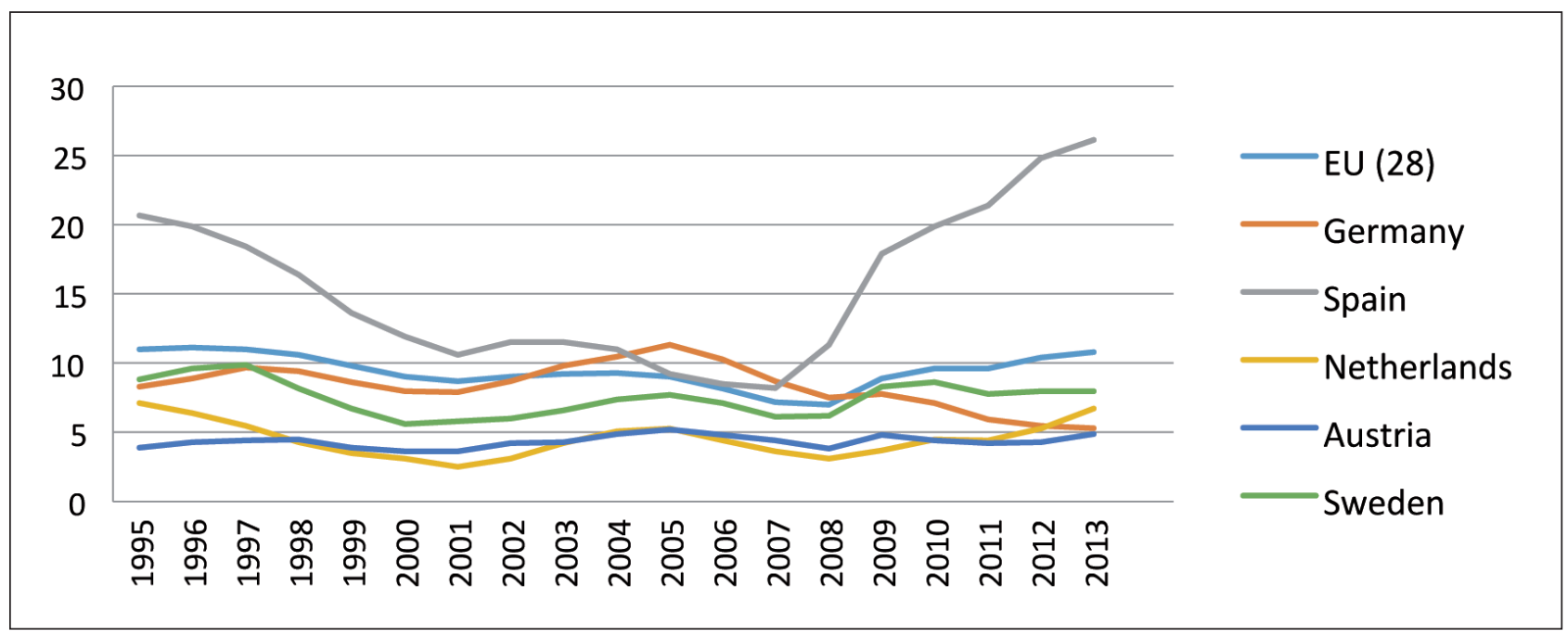

Source: Eurostat 2014 - Accessed on 2nd of Dec. 2014 
councils have the right to negotiate a social plan in the event of management decisions involving restructuring which may lead to job losses. Works councils are also entitled to appoint supervisory board members within the framework of one-third participation by employees in certain large undertakings (Risak 2010).

Notwithstanding the formal separation of trade unions and works councils established by the Labour Constitution Act, there is a tight interrelationship between works councils and trade unions in everyday work as well as in institutional terms. The vast majority of works council members are also members of trade unions and many of them regard themselves as the key link between trade unions and (potential) union members (Pernicka/ Aust 2007, 33f.). As regards the democratic structure of ÖGB, works councils can even be seen as incorporated into the trade union structure. The works council elections are de-facto an integral part of the ÖGB organisational structure in the sense that these elections serve internally as primary elections on which the election of representatives to all union bodies are based (Traxler et al. 200I). The tight interrelationship of day-to-day practices of works councils and trade unions can also be seen at the level of collective bargaining. As outlined above, the metal industry sets the pattern for collective bargaining which falls in the domain of trade unions. However, the metal industry has also pioneered the continued process of organised decentralisation which has taken place since the mid-I98os. In comparison to processes of disorganisation, organised decentralisation means that sector-level-agreements have deliberately devolved bargaining tasks to the company level (Traxler/Pernicka 2007, 22I). This process began with decentralising bargaining over working time and continued with flexible pay that has been an issue since the rg9os. These developments have not only led to an increasing workload of management and works councils, it has also blurred the formal boundaries between trade unions and works councils in that the latter are now involved in distributional issues at enterprise level (a task previously preserved to trade unions at sector level).

Given the new role and functions of works councils it is even more problematic that the number of works councils has been continually declining over the past decades. Unfortunately, data on the development of works councils over time do barely exist. According to Hermann and Flecker (2009, IOo) $58 \%$ of all blue collar workers and $54 \%$ of all white collar-workers are represented by a works council. In the public sector with a similar system of workplace-level representation, $90 \%$ of the workforce is represented. While in small and medium-sized companies works councils are very rare, large establishments with more than I,OoO employees have a coverage rate of almost Ioo percent (ibid.). While the proportion of public sector employees who have a workplace representation has continually increased over the past five years, in the private sector the proportion of employees represented by a works council has sharply decreased. The share of employees and workers who are represented by any workplace representation has fallen from $63 \%$ in 2003 to $48 \%$ in 2013 (AK Oberösterreich 20I3). There is an uneven distribution of works councils by sector. While in tourism, agriculture and forestry, retail trade and company-related services the probability to have a works council is lowest, more than $80 \%$ of teachers and bank employees are represented by a works council (ibid.). Moreover works councils are neither legally entitled nor willing to represent the growing groups of free service contract holders and economically dependent self-employed persons. Even if the work situation of these groups resembles those of dependent employees, they are often neither covered by labour law (including the right to establish a works council) nor by collective agreements. A particular type of non-standard employment is temporary agency work which involves a triangular relationship. This relationship consists of an employment relationship between the temporary agency worker and the temporary work agency; a contractual relationship between the agency and the hiring company that deploys temporary agency workers in the production process; and a relationship between the hiring company and the worker that includes certain employer' duties on the side of the company. Existing works councils in both companies (agency and hiring company) are entitled to represent the temporary agency workers. However, as temporary agency workers are often deployed for a limited period of time the actual relationship between them and works councillor is rather weak.

\section{(IV) Initial vocational education and training and the skill formation system}

The Austrian collective skill formation system is characterised by a strong role of firms and the state that both invest in a coordinated way in initial vocational education and training (IVET) (Trampusch/Busemeyer 20I2). IVET provides the foundations of occupational labour markets in which occupations play a key role in the organisation of work and as underpinning wage determination in collective agreements. In this regard IVET system functions as an important transmission belt between the education system and the labour market (Müller/Gangl 2003).

Austria has - in international comparison - an outstanding system of initial vocational education and training at upper secondary level. IVET serves roughly two thirds of the 15-19 old pupils as a foundation for either being transferred into postsecondary or higher education or entering the labour market. IVET is closely 
related to an employment system that takes - in stark contrast to organisational labour markets (Maurice et al. 1986; Marsden 1999) - broad and standardised occupations as a major building block ${ }^{8}$. In addition to strongly relying on broad vocational qualifications, firms also contribute to the skill formation of their workforce by transferring large groups of employees to more demanding work, by allowing for work-place learning and by granting considerable high levels of job discretion (Holm et al. 20IO). Besides these firmly established organisational principles that aim to facilitate learning in the work process, firms invest in continuing vocational education and training (CVET) (CEDEFOP 2OIO). However, similar to Germany, CVET plays a far lesser role than IVET. Although Austrian social partners have some strong-holds in the provision of CVET (e.g. by running own training institutes which dominate the CVET market), there are only few agreements on CVET between the social partners (Trampusch/Eichenberger 20II). ${ }^{9}$

Although the Austrian skill formation system in general and IVET in particular is regarded as a success story by domestic politicians of all ideological camps, the system is characterised by high levels of horizontal stratification. Dependent on the occupation chosen, formally similar levels of education provide different career opportunities and income levels (Gerber/Cheung 2008; Hefler et al. 20I2) which in turn contribute to the dualisation of the workforce. However, dualisation has been rather inbuilt into the system for a long period and - different to Germany (Thelen/Busemeyer 2012) has not been reinforced by recent reforms.

In the following section we discuss selected developments in the Austrian system of skill formation with a special emphasis on IVET from 1990 to 2014 and examine the social partners' role in (re)producing the patterns of stability or change. We base our discussion mainly on recent research taking a cross-country comparative perspective (Trampusch 2009; 20IO; Graf et al. 2012; Ebner 2013; Trampusch/Eichberger 20I2; Graf 2013). Due to space restrictions, this discussion has to be confined to a number of selected features. ${ }^{10}$

We argue that the Austrian IVET system has received sustained support across the political divide and by both employer and employee organisations. Contrary to highly contested reforms of lower secondary educa-

8 On the specific complexities of the Berufsprinzip in Austria, see Lassnigg $2012 b$.

9 A recent new development (2OI4) is the creation of a training fund by the Social Partners. The fund - a new approach for Austria - is called for by an amendement of the law on temporary agency work, for safeguarding CVET for temporary agency workers; see www. swf-akue.at/ (Latest Access 27th of Nov 20I4).

Io Further overviews of the Austrian IVET/CVT system available in English could be found in Hoeckel (2OIO), Hefler et al. (2OI3); for an overview on the recent policy developments in IVET (in German) Lassnigg (20I2a); for the dual apprenticeship see Dornmayr/Novak 20I4a (in English) and 20I4b (in German). tion and higher education (HE), the observed period has seen no major reform of the foundations of the IVET system. However, social partners implemented minor adjustments to account for changing demographic, societal and economic trends (Subsection I). In addition, social partners introduced new institutions such as the so-called supra-company training programme (Überbetriebliche Lehrausbildung) (Dornmayr and Nowak 2OI4) to compensate for a lack in firm-based apprenticeship supply and to strengthen institutionalised routes from dual apprenticeship towards higher education (Subsection 2).

\section{Four levels of IVET}

The IVET system at upper secondary level is typically attended by 15 to 18 or 19 year olds combining two school-based and two apprenticeship-based types of programmes with nearly equal proportions of pupils in the school-based and apprenticeship-based tracks. This combination of equally strong school-based and apprenticeship-based tracks is rather unique in $\mathrm{Eu}$ rope. Only the Czech Republic, the Slovac Republic and the Netherlands display comparable patterns (Lassnigg 20I2a). In Austria, like in Germany and contrary to the development of vocational training in liberal market economies (Bosch and Charest 2008) IVET is not just a 'second best' alternative but enjoys high social esteem. In the following section its different tracks are linked to the educational stratification system. Important differences within each track are outlined to contribute to a better understanding of the considerable high levels of horizontal stratification of the IVET system itself.

At the top of the stratification system are the vocational colleges (Berufsbildende höhere Schulen). They provide five year long programmes and include a combination of VET and academic education. They grant higher education permission after passing the final examination referred to as Reifeprüfung or Matura. Matura at vocational colleges include a defined number of occupational qualifications and connected rights (e.g. to start a business of a particular kind). The schools have a high reputation among parents and employers alike. A quarter of a cohort enters this type which is regarded as equally prestigious as academic upper secondary education. Pupils come both from well-off and disadvantaged families, while few pupils have a migrant background. Vocational colleges accept pupils with a strong performance at lower secondary level. The schools have especially high standards with only two thirds of the participants manage to complete the programmes. Around half of all graduates take up higher education (HE) within three years after graduation. However, graduates also experience comparatively smooth entrance into the labour market, used to have good prospect for managerial careers and enjoy comparatively high pay levels. Within the sector, techni- 
cal schools are most prestigious, followed by schools in business administration, tourism and services.

In the middle of the stratification system are vocational schools (Berufsbildende mittlere Schulen) which usually take three to four years and provide no transition to HE. These schools are closely attached (in the same buildings, with the same teacher body) to the vocational colleges. Their prestige is highly diverse, with technical schools at the top. Some forms (e.g. in business administration) have seen their prestige and the labour market prospects of their students deteriorating. The schools are also a retreat for failing students in VET colleges or young adults who cannot find a regular apprenticeship. Around one in ten of a youth cohort attends this type of school.

Positioned in the middle of the stratification system, the dual apprenticeship (Duale Berufsausbildung/Lehre) combines about four parts training in an enterprise and one part of training in state-run vocational schools. Participants in these 3-4 year long programmes are regarded mainly as workers, not as pupils. Their employment is based on a special contract with an employer. The employer is obliged to provide practical training while the apprentice is expected to contribute productive work to compensate for the costs of his/her apprenticeship. One third of a cohort receives access to regular apprenticeship system. Dual apprenticeship does not include higher education entrance permission, however, a new scheme allows for combining apprenticeship with a general programme (Lehre mit Matura; see below). Apprentices receive a compensation wage, as determined by collective agreements. 'Earning one's own money' is an important reason for adolescents from underprivileged social groups to enter apprenticeships. The dropout rate is $14.6 \%$ on average, yet up to $24 \%$ in some sectors (Dornmayr/Novak 20I4a). Regular apprenticeships vary strongly in prestige, employment prospects, career opportunities and wages, both by occupational field (e.g. with technical programmes at top and personal services at the bottom) and by employer (with large firms at top and small workshops at the bottom).

At the bottom end of the stratification system range the supra-company training programmes that have been established step by step since the mid-I99os. The system aims to compensate for the strongly declining number of available apprenticeship spells. In principle, the scheme provides the same type of VET education as dual apprenticeship, however, the practical part of education is not offered by a firm, but by an educational organisation running training centres. Participants receive only a small allowance. Despite very high public investments in this type of programme, the prestige of the programme is low and future employment prospects are rather poor. Young adults in the system often come from disadvantaged and/or migrant background. The drop- out rate is very high (about $37.5 \%$ in 2012, see Dornmayr/ Novak 20I4a). However, compared to the German transition system, the Austrian one is small with only about $5 \%$ of one birth cohort entering this type of IVET.

Between 1990 and 2014 policy actors managed to keep the overall structure of IVET system pretty much stable despite significant environmental changes (see Figure 3). These include decreased cohorts of pupils born in Austria who have only been partly made up by migrants. The number of 17 year-olds has dropped from 127,000 in 1985 to 87,000 in 2013 , while the proportion of upper secondary students with migrant background roughly increased from one in ten to one in five. With changes in the economic structure the number of available apprenticeship spells fell dramatically in the late I 980 s (by $17 \%$ between 1985 and I990) and could only be stabilised in the following two decades by continuous concerted action of the consecutive governments and the social partners.

In addition to their role in legislative reforms (Talós/ Kittel 200I, I93ff.), the Social Partners shape IVET by participating in updating and the renewal of VET programmes (Cedefop 20I3). Their role is less prominent and only informal concerning school-based tracks, displaying the characteristics of a state-led system (Cedefop 2013). However, they are the key actors in the dual apprenticeship system and dominate the board that is responsible for any reform of dual apprenticeship programmes (Berufsbildungsbeirat). Curricula are comparatively frequently renewed and the past two decades have seen high numbers of strongly updated apprenticeship programmes and new apprenticeships in fields with no tradition of apprenticeships at all, especially in the service sector (Markowitsch/Henkel 2005; Cedefop 2013). Finally, the Social Partners (here: The Chamber of Commerce and the Chamber of Labour) play a key role in taking the final examinations and awarding the qualifications.

Stability and institutional conversion of the apprenticeship system

As in Germany and Switzerland, the Austrian system of dual apprenticeship came under heavy pressure from different sides in the late I980s and early I990s, respectively.

As stated, in the late 1980 the available apprenticeships provided by firms decreased by $17 \%$ within five years (see Figure 2). In addition, structural changes hollowed out the most traditional apprenticeships in trades and manufacturing. Second, educational expansion and a preference for programmes allowing access to higher education have brought more 15 year olds into VET colleges and academic schools (Gymnasien). Moreover, the introduction of universities of applied sciences (Fachhochschulen) in 1994 challenged the career opportunities 
Figure 2. Development of apprentices from 1985 to 2013

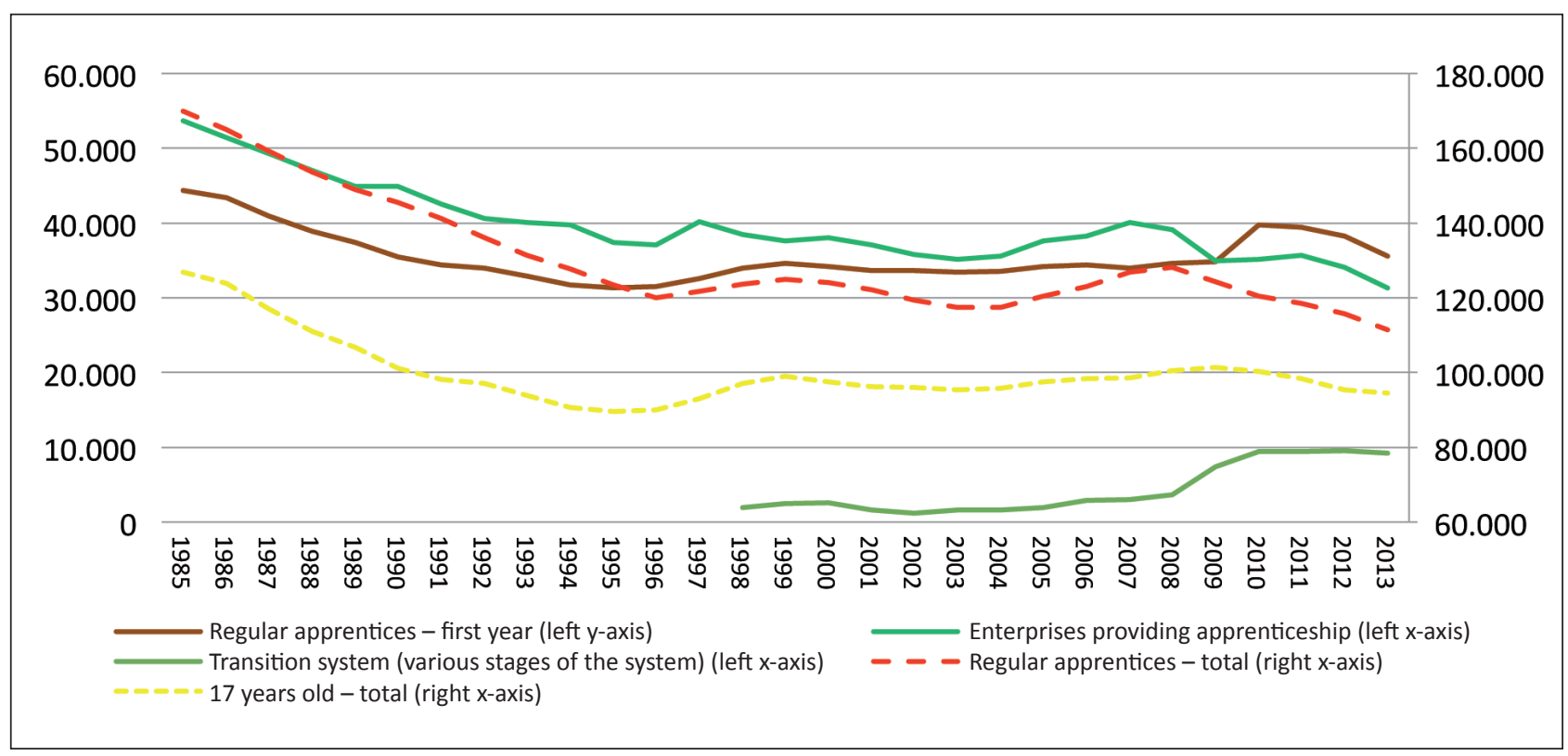

Sources: Dornmayr and Nowak 2014b, own calculations

of former apprentices rendering the pathway from apprenticeship to management or more advanced professional positions more unlikely ('academic glass ceiling'; Bosch 20I4). Third, the declining demand for unskilled labour (or for workers without considerable levels of formal qualification, even when doing unskilled work) closed the pathway for I5 years old into unskilled employment.

Under changing government coalitions, the Social Partners have contributed to the formal stabilisation and institutional conversion of the dual apprenticeship system from the mid of the iggos until today.

First, various reforms of apprenticeship programmes were introduced. Their number was reduced by combining programmes and hence, broadening vocational domains. Contrary to Germany, the duration of programmes was not shorted, but more frequently expanded. Moreover, new types of apprenticeship programmes were established in the service sector, often 'from scratch' with no forerunners in the particular field. The strong legitimacy of the institutional model apprenticeship) and the considerable state support open the ways into new fields such as the fast-food industry or Information Technology (IT). ${ }^{\text {I }}$

Second, taking various intermediary steps, co-funding schemes have become institutionalised which sup-

II However, no form of 'higher apprenticeship', requiring academic secondary education as a formal or de-facto entrance requirement has been introduced (for the different situation in Germany, Baethge 20IO). VET colleges leave little space for a strong 'upgrading' of dual apprenticeship. IVET programmes also have not systematically 'downgraded' within the stratification system. port firms that provide apprenticeships. Apart from paying for the school-based part, public contributions to firms' costs continuously increased. State co-funding should be seen against the backdrop of firms' comparatively low average costs for apprentices in Austria (Beicht et al. 2004; Lassnigg 20I2a). For some sectors with high numbers of apprentices and a low proportion of young adults staying on in the sector (e.g. hairdressing), it is an open secret that apprentices are the cheapest labour available.

Third, former projects within active labour market policies for young people without access to regular apprenticeship places have become accepted as serving a permanent need (Schneeberger 2009). Legal reforms make it possible that providers in active labour market policies offer practical 'workshop training', replacing the firm-based component of dual apprenticeship. It is noteworthy that the supra-company training programmes forming the Austrian 'transition system' (Dornmayr/ Novak 2OI4a; 20I4b) entail higher costs than any other form of upper secondary education.

Forth, to increase the attractiveness of dual apprenticeship, new routes for former apprentices into higher education have been established. While opportunities for entering $\mathrm{HE}$ for former apprentices have existed since the late I94Os, it took until I997 and the introduction of a special examination, the Berufsreifeprüfung to allow a greater number of former apprentices to enter higher education. The introduction of Berufsreifeprüfung marks a breakthrough both in general education and IVET (see Markowitsch et al. 20I3). While the Berufsreifeprüfung is available only for adults (I8+) and subject to considerable 
fees $^{12}$, the same scheme under a new name (Lehre mit Matura) has been made available to regular apprentices $\left(15^{+}\right)$ and fully paid by public funds. In 2012 , already $6 \%$ of all apprentices have entered the Lehre mit Matura scheme. The new provision is a particular good example of institutional bricolage leading to conversion, where existing elements of a system are recombined for new aims without formally changing any major pillar of the system.

Through the combination of various initiatives, the Social Partners succeeded in stabilising the dual apprenticeship system, which arguably plays a key role in the occupational structure of the Austrian labour market. While in the aftermath of the recent economic crisis available number of apprenticeships positions provided by firms have dropped again, supra-company training programmes have proven their strength (see figure 3; Dornmayr/Novak 20I4b). However, it is noteworthy that reforms hardly address the well-known weaknesses of the system, as for example, the strong gender-segregation, putting female students at disadvantage and the discrimination of young adults with migrant backgrounds. In addition, these reforms have hardly changes the situation that IVET is a career opener for some occupations and a kind of dead end for others. Most interestingly, policy prescriptions deriving from the European Union (e.g., National Qualifications Framework (NQF) (Lassnigg 20I2a; Markowitsch 2009) contribute little to improve the situation.

\section{Conclusions}

A central goal of this article has been to evaluate the development of Social Partnership in Austria and to contribute to a better understanding of institutional change and stability in coordinated market economies. Notwithstanding ongoing processes of liberalisation and disorganisation in all capitalist economies (Streeck 20IO), more recent accounts of the VofC-literature have emphasised different varieties of liberalisation. In conservative-corporatist countries, like Germany, 'dualising liberalisation' (Thelen 2012; 2014) has been identified as the ideal-typical trajectory of liberalisation, resulting in an organised core (mainly in manufacturing) and unorganised fringes where employees are not covered - among other institutions - by collective agreements or firm-based training schemes. Apart from historical reasons (e.g., German reunification) this pattern of liberalisation has been explained by a cross-class coalition that unites rather than separates segments of labour and capital, however, in the context of a distinct narrowing in the number of firms and workers covered by result-

I2 Fees used to exceed 2000 Euros for the preparation programme (Markowitsch et al. 2013), however, public co-funding is available in many Austrian regions (Länder). ing agreements (Thelen 2014, I4). In strong contrast to the German situation, Austrian institutions of co-ordination and Social Partnership have been found to display a remarkable resilience across distinct institutional fields. From an actor-centred perspective on institutions a possible explanation stems from Power Resource Theory (Korpi 1983) that would attribute institutional stability of Austrian Corporatism to the strength of the organised labour movement. Measured by their organisational strength (unions have lost half of their membership within the last three decades) or by their structural power (there has been a considerable increase in unemployment), Austrian trade unions barely fulfil these underlying premises of institutional stability. Instead, Austrian Corporatism rather rests on the institutional pillars of Social Partnership that has taken on many different forms: In economic and social policy-making, all political parties except the Populist Freedom Party (and the BZÖ) have been strongly committed to the informal role of Social Partnership and a political culture of compromise. In collective wage bargaining the Chamber of Commerce in particular defended the core institution underlying the broad coverage of collective agreements, i.e., compulsory membership in the Austrian Chambers, against harsh political attacks mounted mainly by FPÖ politicians during their participation in government. Institutions of co-determination at company and plant level are mainly based on labour law. And initial vocational training and education rest on both regulative and non-regulative institutions that provide organised labour and business with privileged access to political as well as administrative issues. Against this background, labour and business actors have contributed to an institutional conversion of Social Partnership towards new purposes in an internationalised context. This included a transformation from demand-side towards supply-side Corporatism, processes of organised decentralisation in wage policies and the development of new institutions to compensate for a lack of enterprise based apprenticeship spells. Standardised occupations provide such firmly institutionalised links between individual workers, initial vocational education and training, the labour market and collective wage agreements in Austria that neither employers nor labour unions would seriously draw them into question.

However, during the government coalition of the conservative People's Party and the populist Freedom Party (2000-2006) it became clear that the normative commitment to Social Partnership would reach the limits of its capacity if the power-balance shifted towards a more neoliberal stance. Institutional power resources are therefore seen as providing 'borrowed stability' rather than a robust basis for the resilience of Austro Corporatism. Trade unions in particular are required to shift their orientation towards their membership and 
find new ways of combining their role as a Social Partnership organisation vis-à-vis business and government on the one hand and as membership/conflict-oriented social movement organisation on the other hand in order to safeguard non-market institutions in Austria.

\section{Literature}

Ashton, David N./Francis Green (1996). Education, training and the global economy, Cheltenham.

Atzmüller, Roland (2009). Die Entwicklung der Arbeitsmarktpolitik in Österreich. Dimensionen von Workfare in der österreichischen Sozialpolitik, in: Kurswechsel (4), 24-34.

Arbeiterkammer Österreich (2015). Arbeiterkammerwahl $2014 \mathrm{zu}$ Ende: FSG baut absolute Mehrheit aus, internet: www.arbeiterkammer.at/ueberuns/akwahl/ AK_Wahl_2OI4.html (accessed on I4.04.20I5).

Arbeiterkammer Oberösterreich (20I3). Arbeitsklimaindex, internet: http://media.arbeiterkammer.at/ oe/ publikationen/arbeitsklimaindex/AKI_2OI3_4_November.pdf (accessed on I3.IO.20I4).

Baccaro, Lucio/Chris Howell (2OII). A Common Neoliberal Trajectory: The Transformation of Industrial Relations in Advanced Capitalism, in: Politics \& Society, Vol. 39(4), 52 I-563.

Baethge, Martin (2010). Neue soziale Segmentationsmuster in der beruflichen Bildung, in: Heinz-Hermann Krüger/Ursula Rabe-Kleberg/Rolf-Torsten Kramer/Jürgen Budde (eds.): Bildungsungleichheit revisited Bildung und soziale Ungleichheit vom Kindergarten bis zur Hochschule, Wiesbaden, 275-298.

Bauer, Stefan (20I0). Die kollektivvertragliche Deckungsrate in Österreich: Analyse, Darstellung und Diskussion der kollektivvertraglichen Deckungsrate sowie der damit verbundenen Problembereiche, Diplomarbeit, University of Vienna.

Beicht, Ursula/Hermann Herget/Günter Walden/Bundesinstitut für Berufsbildung (2004). Costs and benefits of in-company vocational education and training in Germany, Bielefeld.

BMASK (2OI3). Sozialbericht 2OII-20I2. Ressortaktivitäten und sozialpolitische Analysen, Vienna.

Bosch, Gerhard (2014). Facharbeit, Berufe und berufliche Arbeitsmärkte, in: WSI-Mitteilungen, Vol. 67(I), 5-I3.

Busemeyer, Marius R./Christine Trampusch (2012). The Comparative Political Economy of Collective Skill Formation, in: Marius R. Busemeyer/Christine Trampusch (eds.): The Political Economy of Collective Skill Formation, Oxford, 3-38.

Cedefop (2010). Employer-provided vocational training in Europe - Evaluation and interpretation of the third continuing vocational training survey, Luxembourg.
Cedefop (20I3). Renewing VET provision - Understanding feedback mechanisms between initial VET and the labour market, Research Paper 37, Luxembourg.

Crouch, Colin (2006). Skill Formation Systems, in: Stephen Ackroyd/Rosemary Batt/Paul Thompson/Pamela S. Tolbert (eds.): The Oxford Handbook of Work and Organization, Oxford, 95-II4.

DiMaggio, Paul (1988). Interest and agency in institutional theory, in: Lynne G. Zucker (ed.), Institutional patterns and organizations: culture and environment, Cambridge, 3-2I.

DiMaggio, Paul/Walter Powell (1983). The iron cage revisited: Institutional isomorphism and collective rationality in organizational fields, in: American Sociological Review, Vol. 48, I47-I6o.

Dornmayr, Helmut/Sabine Nowak (2014). Survey of Apprenticeship Training in 2014, in: Structural Data, Trends and Prospects, ibw research brief 84 .

Dornmayr, Helmut/Sabine Nowak (20I4b). Lehrlingsausbildung im Überblick 20I4, Strukturdaten, Trends und Perspektiven, ibw-Forschungsbericht I80.

Ebner, Christian (2013). Erfolgreich in den Arbeitsmarkt? - Die duale Berufsausbildung im internationalen Vergleich, Frankfurt/Main.

Estevez-Abe, Margarita/Torben Iversen/David W. Soskice (200I). Social protection and the formation of skills: a reinterpretation of the welfare state, in: David W. Soskice/Peter A. Hall (eds.): Varieties of capitalism: the institutional foundations of comparative advantage, Oxford, I45-183.

Eurofound (2014). Austria: Impact of the crisis on industrial relations, EIRO, Dublin, internet: http://eurofound.europa.eu/observatories/eurwork/comparative-information/national-contributions/austria/ austria-impact-of-the-crisis-on-industrial-relations (accessed on 28.II.2OI4).

European Trade Union Confederation (ETUC) (2000). The Coordination of Collective Bargaining, Resolution adopted at the ETUC Executive Committee, I3-I4 December, Brussels.

Falkner, Gerda/Simone Leiber (2004). Europeanisation of Social Partnership in Smaller European Democracies?, in: European Journal of Industrial Relations, Vol. IO(3), 245-266.

Finegold, David/David Soskice (1988). The Failure of British Training: Analysis and Prescription, in: Oxford Review of Economic Policy, Vol. 4(3), 2 I-53.

Flecker, Jörg/Christoph Hermann (2005). Geliehene Stabilität. Zur Funktionsfähigkeit des dualen Systems der Arbeitsbeziehungen in Österreich, in: Ferdinand Karlhofer/Emmerich Tálos (eds.): Sozialpartnerschaft - eine europäische Perspektive, Münster, 37-56.

Flecker, Jörg/Annika Schönauer (20I3). European diversity of worksharing as a crisis measure: The experiences of Austria, Belgium, France and the Netherlands, in: 
Jon Messenger/Naj Ghosheh (eds.): Work Sharing during the Great Recession, New Developments and Beyond, Cheltenham, 72-98.

Gallie, Duncan (2013). Economic crisis, quality of work, and social integration: the European experience London, Oxford.

Gerber, Theodore P./Sin Yi Cheung (2008). Horizontal Stratification in Postsecondary Education: Forms, Explanations, and Implications, in: The Annual Review of Sociology, Vol. 34, 299-318.

Gingerich, Daniel/Peter Hall (2004). Varieties of Capitalism and Institutional Complementarities in the Macroeconomy. An Empirical Analysis, MPIfG Discussion Paper 04/5, Cologne, internet: www.mpifg. $\mathrm{de} / \mathrm{pu} / \mathrm{mpifg}$ dp/dpo4-5.pdf (Accessed on 5.IO.2OI4).

GPA-DJP (2015). Interview with Christoph Sykora, in charge of marketing and organising within this trade union, interview (30.3.2015).

Graf, Lukas (2013). The hybridization of vocational training and higher education in Austria, Germany, and Switzerland, Opladen.

Graf, Lukas/Lorenz Lassnigg/Justin J. W. Powell (2012). Austrian Corporatism and Institutional Change in the Relationship between Apprenticeship Training and School-Based VET, in: Marius R. Busemeyer/ Christine Trampusch (eds.): The Political Economy of Collective Skill Formation, Oxford, I50-178.

Green, Francis (2013). Skills and Skilled work - An economic and social analysis, Oxford.

Hall, Peter/David Soskice (200I). Varieties of Capitalism: The Institutional Foundations of Comparative Advantage, Oxford.

Hancké, Bob (20I3). The missing link. Labour unions, central banks and monetary integration in Europe, in: Transfer: European Review of Labour and Research, Vol. I9(I), 89-IOI.

Hassel, Anke (2014). The Paradox of Liberalization - Understanding Dualism and the Recovery of the German Political Economy, in: British Journal of Industrial Relations, Vol. 52(I), 57-8I.

Hefler, Günter/Genoveva Brandstetter/Silvia Zimmel/Jörg Markowitsch (2012). Austria, in: Samo Pavlin/Julian Stanley (eds.): Experiencing VET in Europe - Insights into the Learning Experiences of $\mathrm{I} 7$ and 18 Year Old VET Students in 7 EU Countries - Results from an international survey, Ljubljana, 70-II5.

Hefler, Günter/Jörg Markowitsch (2012). Bridging Institutional Divides: Linking education, careers and work in 'organizational space' and 'skill space' dominated employment systems, in: Rachel Brooks/Alison Fuller/ Johanna Waters (Eds.): Changing Spaces of Education - New Perspectives on the Nature of Learning, London, I60-I8I.

Henkel, Susanne/Jörg Markowitsch (2005). Analyse der Kommunikationsprozesse in vier Berufsbildungs- teilsystemen [Analysis of the communication processes in four vocational training subsystems], in: Lorenz Lassnig/Jörg Markowitsch (eds.): Qualität durch Vorausschau. Antizipationsmechanismen und Qualitätssicherung in der österreichischen Berufsbildung, Innsbruck/Vienna, 3I-75.

Hermann, Christoph/Karl Hinrichs (2012). Die Finanzkrise und ihre Auswirkungen auf Sozialstaaten und Arbeitsbeziehungen - ein europäischer Rundblick, Eine Studie im Auftrag der Arbeiterkammer Wien, November 20I2, Vienna.

Hermann, Christoph/Jörg Flecker (2009). Das „Modell Österreich“ im Wandel, in: Christoph Hermann/Roland Atzmüller (eds.): Die Dynamik des „österreichischen Modells“. Brüche und Kontinuitäten im Beschäftigungs- und Sozialsystem, Berlin, I7-44.

Hoeckel, Kathrin (20IO). OECD Reviews of Vocational Education and Training - A Learning for Jobs Review of Austria, Paris.

Holm, Jacob R./Lorenz Edward/Lundvall Bengt-Åke/Antoine Valeyre (20IO). Organizational learning and systems of labor market regulation in Europe, in: Industrial and Corporate Change, Vol. I9(4), II4I-II73.

Höpner, Martin/Mark Lutter (20I4). One Currency and Many Modes of Wage Formation, MPIfG Discussion Paper I4/I4, Köln.

Karlhofer, Ferdinand (2007). Filling the Gap? Korporatismus und neue Akteure in der Politikgestaltung, in: Österreichische Zeitschrift für Politikwissenschaft, Vol. 36(4), 389-403.

Karlhofer, Ferdinand (20I2). Zwischen Korporatismus und Zivilgesellschaft, in: Werner Reutter (ed.): Verbände und Interessengruppen in den Ländern der Europäischen Union, 2nd edition, Wiesbaden, 52I549.

Knittler, Käthe/Bettina Stadler (20I2). Atypische Beschäftigung während der Krise nach sozialdemografischen Merkmalen, in: Statistische Nachrichten (7), Vienna.

Koike, Kazuo/Takenori Inoki (eds.). (I990). Skill formation in Japan and Southeast Asia, Tokyo.

Korpi, Walter (1983). The Democratic Class Struggle, London.

Krings, Torben (20I3). Von der "Ausländerbeschäftigung" zur Rot-Weiß-Rot-Karte: Sozialpartnerschaft und Migrationspolitik in Österreich, in: Austrian Journal of Political Science, Vol. 42(3), 263-278.

Lash, Scott/John Urry (1987). The End of Organized Capitalism, Cambridge.

Lassnigg, Lorenz (2012a). Die berufliche Erstausbildung zwischen Wettbewerbsfähigkeit, sozialen Ansprüchen und Lifelong Learning - eine Policy Analyse, in: Barbara Herzog-Punzenberger (ed.): Nationaler Bildungsbericht Österreich 2012, Band 2, 
Fokussierte Analysen bildungspolitischer Schwerpunktthemen, Graz, 313-354.

Lassnigg, Lorenz (2012b). Beruflichkeit in Österreich: Institutioneller Rahmen für komplexe Koordination und vieldeutige Versprechungen, in Axel Bolder/ Rolf Dobischat/Günter Kutscha/Gerhard Reutter (eds.): Beruflichkeit zwischen institutionellem Wandel und biographischem Projekt, Wiesbaden, 189-217.

Lijphart, Arend (1999). Patterns of Democracy: Government Forms and Performance in Thirty-Six Countries, New Haven, Connecticut.

Mairhuber, Ingrid (2003). Pensionsreform in Österreich: Akteure und Inhalte (1980-2003), FORBA Forschungsbericht I2, Vienna.

Marsden, David. (1999). A Theory of Employment Systems: Micro-Foundations of Societal Diversity, Oxford.

Markowitsch, Jörg (ed.) (2009). Der Nationale Qualifikationsrahmen in Österreich - Beiträge zur Entwicklung, Vienna.

Markowitsch, Jörg/Günter Hefler/Stephanie Rammel/Paul Ringler (2013). Nobody's Darling - Dynamics and Inertia of Formal Adult Education in Austria, in: Ellu Saar/Odd Bjorn Ure/Roosalu Triin (eds.): Lifelong Learning in Europe: National Patterns and Challenges, Cheltenham, 232-257.

Maurice, Marc/Francois Sellier/Jean-Jacques Silvestre (1986). The Social Foundations of Industrial Power A comparison of France and Germany, Cambridge.

Maurice, Marc/Arndt Sorge/Malcolm Warner (1980). Societal Differences in Organizing Manufacturing Units: A Comparison of France, West Germany, and Great Britain, in: Organization Studies, Vol. I(I), 59-86.

Melzer, Manuel (2013). Öffnet sich die Schere zwischen Arm und Reich? Ist das überhaupt ein Problem?, internet: http://blog.arbeit-wirtschaft.at/oeffnet-sichdie-schere-zwischen-arm-und-reich-ist-das-ueberhaupt-ein-problem (accessed on 5.IO.20I4).

Mayer, Karl Ulrich/Solga, Heike (eds.) (2008). Skill Formation - Interdisciplinary and cross-national perspectives, Cambridge.

Müller, Walter/Markus Gangl (eds.) (2003). Transitions from Education to Work in Europe the Integration of Youth into EU Labour Markets, Oxford.

Müller, Wolfgang C./Marcelo Jenny (2004). „Business as usual" mit getauschten Rollen oder Konflikt- statt Konsensdemokratie? Parlamentarische Beziehungen unter der ÖVP-FPÖ-Koalition, in: Österreichische Zeitschrift für Politikwissenschaft, Vol. 33(3), 309-326.

Musset, Pauline/Simone Bloem/Mihály Fazekas/Simon Field (2OI3). OECD Reviews of Vocational Education and Training. A Skills beyond School Review of Austria, Paris.
Obinger, Herbert (2009): Sozialpolitische Bilanz der Großen Koalition in Österreich, in: Herbert Obinger/ Elmar Rieger, et al. (eds.): Wohlfahrtsstaatlichkeit in entwickelten Demokratien: Herausforderungen, Reformen und Perspektiven, Festschrift für Stephan Leibfried, Frankfurt/Main, 347-374.

OECD (2014). Trade Unions: Trade union density, OECD Employment and Labour Market Statistics (database). DOI: I0.I787/data-0037I-en (Accessed on 8.II.2OI4).

Pernicka, Susanne (2005). The Evolution of Union Politics for Atypical Employees. A Comparison between German and Austrian Trade Unions in the Private Sector, in: Economic and Industrial Democracy, Vol. 26(2), 2OI-224.

Pernicka, Susanne (2006). Organising Dependent SelfEmployed Workers: Theoretical Considerations and Empirical Findings, in: European Journal of Industrial Relations, Vol. I2(2), I23-I4O.

Pernicka, Susanne/Ulrike Mühlberger (2009). Abhängige Selbstständigkeit in der Versicherungswirtschaft - Neue Konflikte im Spannungsfeld traditioneller Vertretungsstrukturen, in: Zeitschrift für Personalforschung, Vol. 23(I), 28-46.

Pernicka, Susanne/Andreas Aust (2007). Die Unorganisierten gewinnen. Gewerkschaftliche Rekrutierung und Interessenvertretung atypisch Beschäftigter ein deutsch-österreichischer Vergleich, Berlin.

Pernicka, Susanne/Sandra Stern (2OII). Von der Sozialpartnergewerkschaft zur Bewegungsorganisation? Mitgliedergewinnungsstrategien österreichischer Gewerkschaften, in: Austrian Journal of Political Science, Vol. 4O(4), 335-355.

Pernicka, Susanne/Vera Glassner (20I4). Transnational strategies of trade unions towards wage policy. A neoinstitutional framework, in: European Journal of Industrial Relations, Vol. 2O(4), 317-334.

Risak, Martin E. (2010). Labour Law in Austria, Alphen aan den Rijn.

Schmitter, Philippe (1974). Still the Century of Corporatism?, in: The Review of Politics, Vol. 36(I), 85-I3I.

Schmitter, Philippe/Wolfgang Streeck (1999). The Organization of Business Interests: Studying the Associative Action of Advanced Industrial Societies, MPIfG Discusion Paper 99/I, Köln.

Schneeberger, Arthur (2009). Bildungsgarantie bis zum 18./19. Lebensjahr - Entwicklungen und Perspektiven in der Berufsbildung, in: Werner Specht (ed.): Nationaler Bildungsbericht Österreich 2009 - Band 2 - Fokussierte Analysen bildungspolitischer Schwerpunktthemen, Graz, 55-72.

Streeck, Wolfgang (199I). On the institutional conditions of diversified quality production, in: Egon Matzner/ Wolfgang Streeck (eds.): Beyond Keynesianism - The 
Socio-Economics of Production and Employment, London, 2I-6I.

Streeck, Wolfgang (20IO). Re-Forming Capitalism: Institutional Change in the German Political Economy, Oxford.

Streeck, Wolfgang (20I4). Buying time: the Delayed Crisis of Democratic Capitalism, London.

Streeck, Wolfgang/Philippe Schmitter (1985). Private Interest Government. Beyond Market and State, London.

Streeck, Wolfgang/Kathleen Thelen (eds.) (2005). Beyond Continuity. Institutional Change in Advanced Political Economies, Oxford.

Tálos, Emmerich (2006). Sozialpolitik. Zwischen Expansion und Restriktion, in: Herbert Dachs/Peter Gerlich/ Herbert Gottweis et al. (eds.): Politik in Österreich. Das Handbuch, Vienna, 624-636.

Tálos, Emmerich (2008). Sozialpartnerschaft. Ein zentraler politischer Gestaltungsfaktor in der Zweiten Republik, Innsbruck.

Tálos, Emmerich/Bernhard Kittel (200I). Gesetzgebung in Österreich: Netzwerke, Akteure und Interaktionen in politischen Entscheidungsprozessen, Vienna.

Tálos, Emmerich/Christian Stromberger (2004). Verhandlungsdemokratische Willensbildung und korporatistische Entscheidungsfindung am Ende?, in: Österreichische Zeitschrift für Politikwissenschaft, Vol. 33(2), I57-I74.

Thelen, Kathleen (2004). How institutions evolve: The political economy of skills in Germany, Britain, the United States and Japan, New York.

Thelen, Kathleen (2008). Skill formation and training, in: Geoffrey Jones/Jonathan Zeitlin (eds.): The Oxford handbook of business history, Oxford, 558-580

Thelen, Kathleen (2012). Varieties of Capitalism: Trajectories of Liberalization and the New Politics of Social Solidarity, in: Annual Review of Political Science, I5, I37-I59.

Thelen, Kathleen (2014). Varieties of liberalization and the new politics of social solidarity, New York.

Thelen, Kathleen/Marius R. Busemeyer (2012). Institutional Change in German Vocational Training: From Collectivism toward Segmentalism, in: Marius R. Busemeyer/Christine Trampusch (eds.): The Political Economy of Collective Skill Formation, New York, 68-100.

Trampusch, Christine (2009). Europeanization and Institutional Change in Vocational Education and Training in Austria and Germany, in: Governance, Vol. 22(3), 369-395.

Trampusch, Christine (2010). Employers, the state and the politics of institutional change: Vocational education and training in Austria, Germany and Switzerland, in: European Journal of Political Research, Vol. 49(4), $545-573$.
Trampusch, Christine/Pierre Eichenberger (20II). Skills and Industrial Relations in Coordinated Market Economies - Continuing Vocational Training in Denmark, the Netherlands, Austria and Switzerland, in: British Journal of Industrial Relations, I-23.

Traxler, Franz (1992). Austria: Still the Century of Corporatism, in: Antony Ferner/Richard Hyman (eds.): Industrial Relations in the New Europe, Oxford, 270-297.

Traxler, Franz (2004). The metamorphoses of corporatism: From classical to lean patterns, in: European Journal of Political Research, Vol. 43(4), 57 I-598.

Traxler, Franz/Alois Guger/Ulrich Rungaldier (200I). Lexikon der Arbeitsbeziehungen, Beschäftigung und soziale Sicherung, Vienna.

Traxler, Franz/Martin Behrens (2002). Collective bargaining coverage and extension procedures'. Comparative Study, European Industrial Relations Observatory, internet: www.eurofound.europa.eu/eiro/ 2002/I2/study/tno2I2IO2s (Accessed on I3.IO.2014)

Traxler, Franz/Susanne Pernicka (2007). The State of the Unions: Austria, in: Journal of Labor Research, Vol. I8(2), 207-232.

Visser, Jelle (2013). ICTWSS Database 3.0. April 20I3, internet: www.uva-aias.net/208 (accessed on 25.08.20I4).

\section{Authors}

Susanne Pernicka is a University Professor of Sociology at the Johannes Kepler University in Linz. Her main fields of research refer to European and transnational employment relations, trade union revitalization strategies and theories of institutional change.

Günter Hefler is a Senior Researcher at 3s research laboratory, Vienna. His main fields of research include the cross-country comparative analysis of adult learning and its institutional underpinning, with special emphasis to formal adult education, workplace learning and organisational dimensions of learning. 